\title{
PRIMARY LYMPHOEPITHELIOMA OF THE NASOPHARYNX
}

\author{
By \\ M. YOSHIDA AND M.SASAKI \\ From the Department of Oto-Rhino-Laryngology, Tokyo Medico-Dental College \\ (Director: Prof. S. Horigucki)
}

A case of lymphoepithelioma of the nasopharynx was reported.

Case: 22-year-old female. First seen 7th Oct. 1953.

History: Nasal bleeding the left side for 4 months.

Findings: Local examination revealed a soft mass on the left side of the nasopharynx. Since the biopsy of this mass showed chronic inflammation, resection was done, using La force's Adenotome.

Histological diagnosis: Schmincke's lymphoepithelioma.

Two months later, metastasis was observed on the left side of neck. Exstirpation was done, and the histological examination revealed anaplastic carcinoma.

Because of its high X-ray sensitivity, deep X-ray therapy was given. $U_{p}$ to the present (about 4 years since first seen) metastasis was founds several times, and $X$-ray therapy or radio-active cobalt irratiation was repeated.

Consulting the literature, the author discussed the histology of the tumor and its treatment.

\section{鼻咽腔リンパ上皮腫の1例

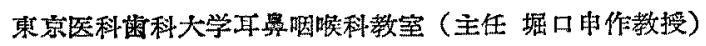 \\ 助手吉思正利 - 助手佳々杰正臣}

緒言

Schmincke ${ }^{1)}$ が 1921 年初めて記載したリンパ上皮腄 は外国にては稀にその報告例を見るが，本邦炕てはその

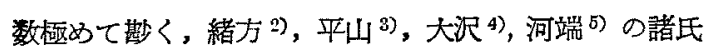
の報告及び最近学会にて名越氏の報告せる症例と数列に 過ぎないものと思われる。

著者等は最近 22 才女子に括いて 䁷咽腔以 原発せる本 症の1例を経験したのでその経過の概要を記し，併せて 若干考察を加光度いと思 5 .

\section{症例}

患者：22 才女子

初診：昭和 28 年 10 月 7 日

主訴. 其出血及び左側耳閐塞感

現病歴：昭和 28 年 6 月 感冒をひき左側耳閉塞感あ
ク，8月中旬に左側悬出血が 4 5 日綕いた事がある.9 月末附近の病院で厌側通気及び鼓膜穿刺を2回受けたが 耳開塞感は消失しなかつた・綿柾で悬の奥を触れると容 易に出血した・某医より紹介されて本学耳悬咽唉科外来 を訪れた。

初浐時所見亚にその後の経過の概要

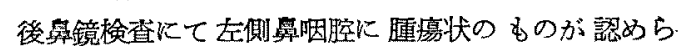
れ，且つ触れるに容易に出颔した。左側鼓膜は混濁し， 且つ通気不良であつた。一見鼠咽腔線維腫を疑わせる所 見であつたので慎重に悬腔より訊験切片を切除したとこ ろ慢性炎症との病理学教堂よりの回答であつた・よつて 11 月 5 日口腔より Laforce 刀にて腫瘍を切除した。切 除に際し出血は卙かつた・切除せる腫瘍の組織学的診断 は Schmincke のリンパ上皮堙であつた（第 1,2 図）。 


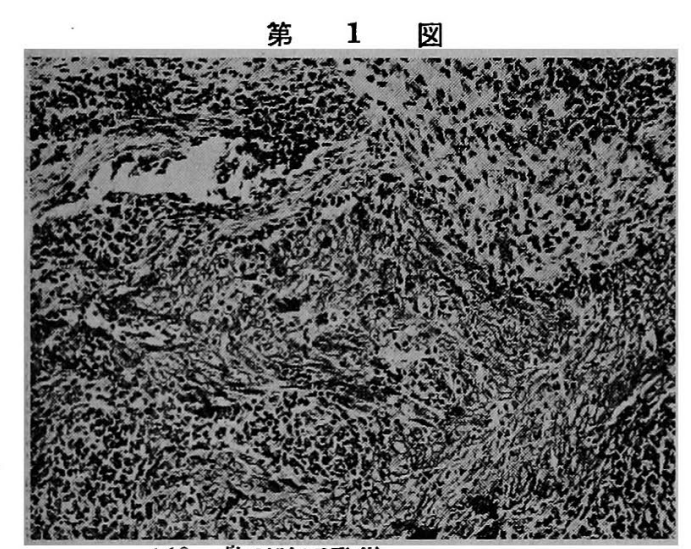

$\times 160$ 悬咽腔原発巢
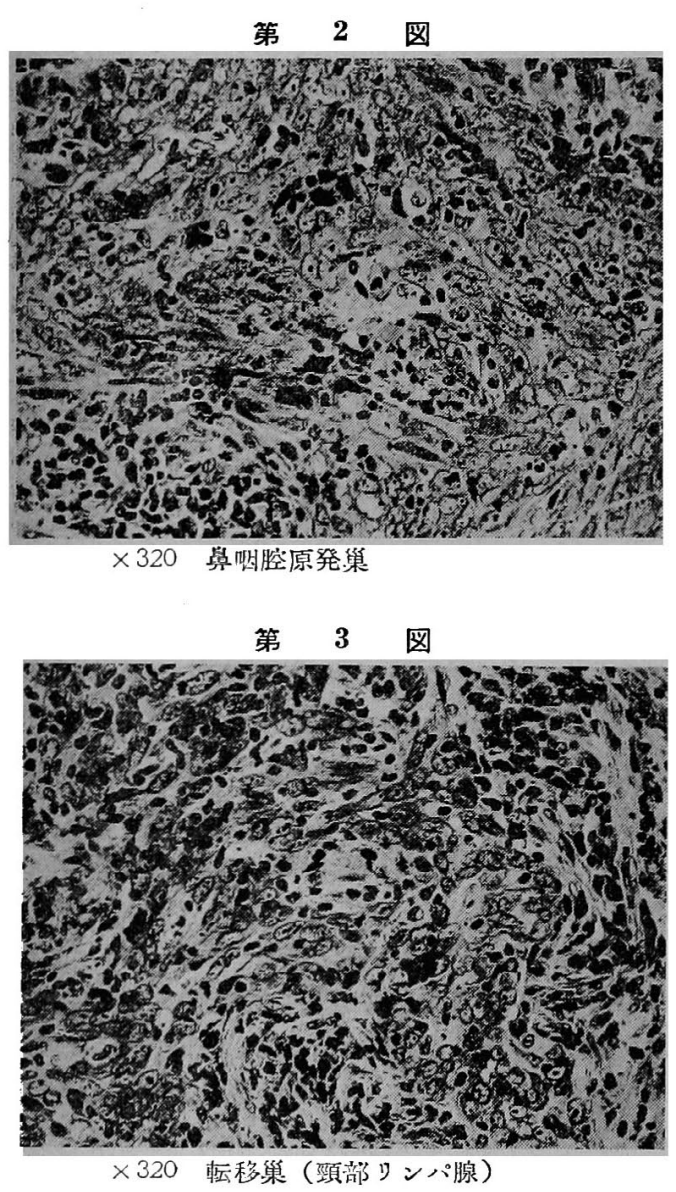

腫㾤摘出後 12 月 20 日頃から左側頸部リンパ腺腫脹が 現れ，これは腫瘍の転移と洘えられたので摘出したとこ つ組織学的䛦断は Anaplastic carcinoma であつた（第
3 図). 摘出後レ線樑部照射を行い同月末に退院した・ 退院後外来に 通院し経過を観察中翌昭和 29 年 6 月に至 り左眼に軽度の眼球突出あり且つ複視を訴えるので再入 院し眼科にて診察を受けたところ, 眼球運動は外側に障 碍あり, 外直筋の外転神経麻疩あるも眼底は異常なしと の診断であつた・よつて顔面レ線写真を種々の方向から 撮影し, 又脳会䯣液検查を施行, 舅咽膑更び眼窩後方に レ線照射を行つたところ，眼科的障碍も消失したので 7 月末一且退院した・退院後は週 1 回来院して経過を観察 していたが，翌昭和 30 年 1 月に 至つて再び眼症状出現 した. 即ち左側眼球運動障碍あり今回は加うるに左顔面 の知党麻瘏あり, 腫瘍の頭蓋内侵入乃至は転移が疑われ る状態に至つた.今回は本学放射線科に入院, 前回同様 梁部療法を施行したところ再び軽快し 2 月初句退院し得 たー而るに 2 月末に至り, 再び軽度の眼球突出あり 4 月 に入り右側胸鎖乳样筋前縁に小指頭大のリンパ腺腫を見 るに至り, 該部及び顔面にレ線深部療法を行つたところ 比輘的簡単に腫脹消失し, 眼球突出も軽快した. 以後外 来にて観察せるに少時平稳状態が続いたが，12月に至 つて 左側鼻腔中舅道に腫瘍が 出現したので昭和 31 年 1 月放射線科に入院, 該腫痬に対し $\mathrm{CO}_{60}$ の治療を行い, 5 月末腫瘍の消失をもつて退院した. 退院後 7 月末に再 び舅閉塞を訴え, 前と同部位に腫瘍の再発を認めたので 再び $\mathrm{CO}_{60}$ を使用したが 今回は奏効せず、10 月中旬以 降放射線科にてレ線多門照射を行い腫瘍の縮少消失を認 め昭和 31 年 12 月退院し, 以後自宅にて療養しつつあ る・な打引続き経過観察中である・

\section{紷括並に考按}

以上の如く本症例はその全経過現在迄 4 年近く, 原発 单たる鼻咽腔を中心として鼻胵・頸部・眼窩周辺と次々 転移が見られその都度あるいは手術，あるいは放射線潦 法が比較的速かに施行され，何れも一応軽快しつ〉今日 に到つたのであるが, 現在迄の本症に関する文献を顧み つ発生頻度・発生部位・症状並に診断・病理組織学的 所見・治療及び予後の各項に就て簡単に考察を加えてみ た。

\section{1) 発生頻度}

本症は稀なるのであつて例觉ば New York の Memorial Hospital では全覀性腫瘴の 2\% (Martin and Blady ${ }^{6)}$ ), San Diego Naval Hospital では訊験切片 検索例 50,000 例中 鼻咽腔リンパ上皮腫 4 例を 8 年間に 見ているに過ぎない(Hartley and LeStrange ${ }^{7)}$ ). 本邦にては緒言にも触れた如く昭和 12 年に東大の緒方, 
平山氏が 17 才男子で肝缄・骨に転移を示した悬咽腔り ンパ上皮腫の1例を報告したのが最初と思われ，次いで 昭和 14 年大沢氏は学会の席上 26 才，33才，24 才の各 年令に発生し且つその何れる原発单を鼻咽腔に存し，何 れる不幸な転帰をとれる、例に就て報告した・河端氏は 17 才女子において兽咽腔の肉腫の診断のもとに切除し， 組織学的にこれがリンバ上皮腫であつた1例を報告して いる.

最近 Rowland ${ }^{8)}$ は69 才男子に見た 鼻咽腔リンバ上

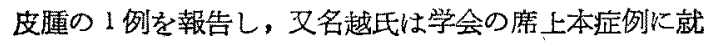
いて報告している.

斯く本症の報告例は比較的稀であるが，最初に記載せ る schmincke 交び本邦にては河端氏も述ふる如く本症 はリンパ肉䭪あるいは扁平上皮癌として診断され処理さ れたものが多数あつたものと思われ，従つて実際の頻度 㟇更に多いるのとみられる。

2) 発生部位

Eggston and Wolff 9) に由れば本症は鼻腔・鼻咽胵・ 咽頭の粘膜並にその上皮がリンパ組織と密接なる関係に 在るところの腸間膜に発生し易く，斯棣な上皮と冺 組織間の密接な関係は正常状態においてい屚桃腺の腺窝 及び兽咽腔のリンバ臚胞に存する.

Willis ${ }^{10)}$ は本症の最も頻発する部位は鼻咽腔側壁の 耳管咽頭開口部附近としているが，著者の例も早期症状 として一過性の耳管狭穿症の所見を呈していた事から恐 らくこの部分に原発したものと思われる。

3) 定状亚に䛦断に就て

初期の症状は整微且つ不定である. Morrison ${ }^{11)}$ 亿由 れば鼻咽腔窖腫の早期症状は極めて軽微であつて屡々無 症状の事さえあると述べている・而して主なる早期症状 として Eggston は咽頭並に耳の不快感, 軽度の留下病, 咽頭及び耳の放散痛を挙げている。これ等症状の中で注 目す可きは耳症状であつて，Willis が原発部位が耳管開 口部に多いために耳症状，特化偏側難聴を早期の症状と して訴える場合が多いと述べているが，著者の例も同 様, 他の何れの症状上り偏側の耳閉塞感・難聴索訴えて いた,

更に重要な事は斯様な軽微且つ不定なる早期症状のた めに早期崄断が遲れる事である。このために多くは頸部 リンパ腺の転移が認められてから診断される事が多いの であるが，著者の例では幸にも頸部りンパ腺腫が少くと す外部から認められる以前に原発腫厡の摘出が行方れ且 つ組織学的袷索が行われたつぬに比較的早期に診断が可
能であった。

\section{4) 病理組織学的所見}

本埂盼の形態学的特徽に関し Eggston and Wolff $K$ 由れば，本婳摽の実質細胞は比較的大きな円形の核を有 し，原形質の輪郭は不明礁であつて，全体として脈絡膜 䄉毛上皮細胞状であると述べているが，著者の例におい ても第 1 , 2 図に見る如くこの記載に一致する腫湯䄄胞 が認められている.病理学教室よりの組織学的所見は 「腫揚組織は不規則似相連続する太い縞状の epitheloid cellsの造る細胞索の交文より成り，その周团及で網目 の中に lymphocytes, lymphfoliiculoid tissue あるい、 は plasma cell を入れ，この部を走る 佔管周团組織は かなり線維が 增加した部分あある。これ等 lymphoid cells と epitheloid cells の集団はかなり明確に境され ているが，後者中に命诸の浸潤も認められる. epithel一 oid cells は大型で紡䤵型の核は大さく，微細なクロ、 チン顆粒と1〜2の核小体を有する・」として「猶，詳細 な検索を必要とするが Schmincke の lymphoepithelial Geschwulst に一致する・」と記載されている。 この所見から理解される如く，本䐈瘍は上皮性㬝湯にし てかなり悪性度の高度なるの，即ち癌腫の一型であり， しかもその origin が結締織性であるところのリンハ組 織と極めて密接なる関係を有して括り，従つてその登生 部位も光に触れた如くリンパ組織の存する部位に限られ るのである. 又本腫塲が癌腫の一型, 特に anaplastic carcinoma であると若える病理学者が多いとの点吱，

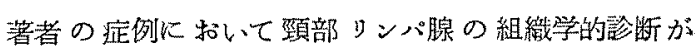
anaplastic carcinoma であつた事実加らも理解される ところである。

5) 治潦亚に予後に就て

本腫場の特徵として放射線に対する感受性が大である 点を挙げる事がでざる。されば治療法に関しては多くの 学者は非手術的療法を推称している。例光ば Kean ${ }^{12}$ ) は「手術は試験切片の切除のみに限定さる可きである山 とし, Martin 13) は鼻咽腔腫疼に対しては手術的寮法の みでは成功する場合が少いと述べている，反之，広範な る手術を推娎する学者すあり，例えば Raven ${ }^{14)}$ は両側 Neck dissection を施行し、リンハ腺腫脹の程拨の軽い 側の内頸静脈更び胸鎖乳㥆筋のみを残存せしむるとい3 徹底した手術を称えている。

著者の例では最初原発巣沉る鼎咽腔から手術的に腫瘍 を除き，次いて頸部リンパ腺転移栄を摘出し，以後は専 ら放射線療法を行つてきたのであるが，斯く比較的容易 
《除去し得る部位，乃至は外かの明視し得る範围内のる のは手術的に除き，梁部のリンパ腺腫脹乃至鼻胭腔にて

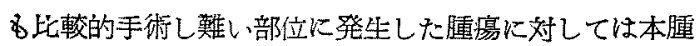

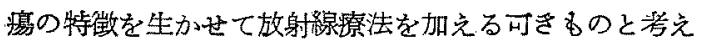
る.

最後に予後に関してよ゙あるが，慗性腫瘍に属するるの 故多くは不良で, 本邦の報告も何れ子不走なる枟帰をと つている.外国交献の夫る同様その大部分が不去な転臣 炎とつており，Rowand は治雭䔞は槡めて低く，早期 にリンパ上皮腫と猃断されしか子充分に沿療が加えられ た例でる 5 年以上生存するるのは約 $1 / 5$ に過さないと述 ベている.

本例は登病以来 4 年, 多くは放射線潦法に頼つてきた のであるが，頻回の放射線療法により腫瘍に対する放射 楾感受性低下が当然考えられ，緒方氏交び最近名越氏が 報告された如く腹腔内淢器に転移をきたし，遂には要液 質に陒り不辛な転帰をとる可能性る考えられるので唒楽 観を許さぬすのと䍐われる。

結語

以上舅咽腔に原発したリンパ上皮腫の1例に就て述べ

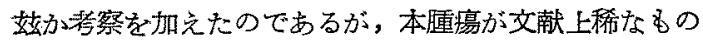
である楒㸬から報告した次第である，先輩諸氏の御教 示・御批判が戴ければ年である・
文献

1) Schmincke, A.: Über Iymphoepitheliale Geschwülste. Beitr. z. path. Anat. u. z. allg. Pathol.

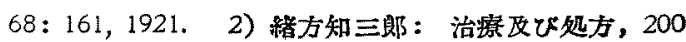

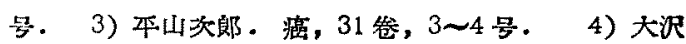

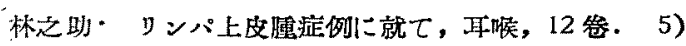
河端一雄；鼻胭柼に発生さ万 Lympho-epithelioma の1例, 耳喉, 13 卷. 6) Martin, H.E. and Blady, J.V.: Cancer of the nasopharynx. Arch. Otol. 32 : 1940. 7) 8) 11) 12) 13) Rowland, A:L.: Primary lympho-epithelioma of the nasopharynx. Annals of Otol. Rhinol. 65 : 1956. 9) Eggston and Wolff: Histopathology of ear, nose and throat. 1947. 10) Willis, R.A.: Pathology of tumors. C.V. Mosby $1953 . \quad$ 14) Raven, R.W.: Cancer of the hypopharynx and its surgical treatment. Brit. Med. Jour. 1: 951 954: 1952.

㩲筆するに当り御格閲它晹つた恩師堀口教授 並に本学病理学教室太田教授に梁々惑謝致しま t.

（原稿到着=昭和 32.4 .12 日）

\section{諎ガーゼは一歩進んだ

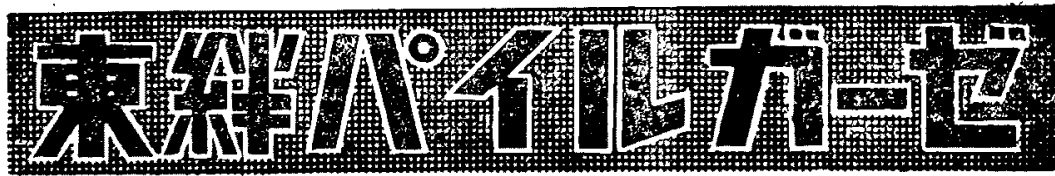

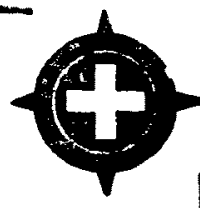

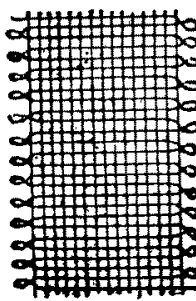

1. 特殊の織り方ですから、耳系がはつれません。 特 2. 詰ガーゼに使用して、伤口に希履が全然残りません。 3. 従つて用法がスムースに行くと同時に思者に余訊な 事苦痛を与えないで夙みます。 4.また再生しても、はつれ糸が出来ません。

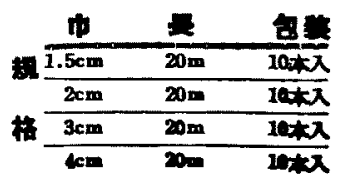

東京絆硘青葲品株式会社 東宗都江户川区进 1 井 98 